\title{
The Effect of Local Crime on Construction Projects in Padang City
}

\author{
Yervi Hesna", Alsidqi Hasan ', Nurhamidah Nurhamidah", Atharika Yosa F \\ \# Department of Civil Engineering, Faculty of Engineering, University of Andalas, Padang, West Sumatra, 25613, Indonesia \\ E-mail: yervi@eng.unand.ac.id; nurhamidah@eng.unand.ac.id; atharika6@gmail.com
}

\author{
*Department of Civil Engineering, Faculty of Engineering, Universiti Malaysia Sarawak, Sarawak, Malaysia \\ E-mail:halsidqi@unimas.edu.my
}

\begin{abstract}
Local crimes often target construction sites for some financial gains. Theft, extortion, and vandalism are common forms of crimes that occurred in a construction project. They can disrupt the process and reduces the contractor's profits. The security in a project site is necessary to maintain the expected productivity and profits, and often, crime is not taken into account in the project plan. Due to this problem, it is crucial to conduct a proper management plan to control construction site security. This paper presents a research outcome on the effects of local crime towards the success of a construction project in Padang, Indonesia. A purposive sampling technique was adopted for the study. The process of data collection involved obtaining primary data from the respondents by conducting questionnaire and structured interviews. The questionnaires were filled-out by professionals from two categories of construction firms, i.e., contractor and force-account private sector. Five contractor type of project and thirty-four force account projects by the private sector were randomly selected. The results showed that the theft occurred more frequently in general contract projects that are managed by the contractor than in the force-account projects. However, the gain-loss due to theft was four times higher in the force account projects than the contractor one. The vandalism occurred more frequently in general contract projects than in the force-account projects. The occurrence of extortion is similar between general contract projects and force account projects. The extortion is found to be the most frequent security problem occurring on construction projects in Padang City, and can potentially increase the project cost.
\end{abstract}

Keywords - security factors; construction; project; cost; schedule.

\section{INTRODUCTION}

Many factors influence the success of project construction for achieving project costs and schedule assigned. The contractors or owners can control the resources and the resources as the most critical factor influencing the schedule $[1,2]$ However, non-technical factors such as security cannot be controlled. Internal and external sites issue are also responsible for cost overrun in building construction projects [3],[4]. The environmental, safety and security factors influence the project schedule [5]. Therefore, a good estimation should cover the construction cost and schedule of a project [6].

Construction job sites present a unique set of issues when addressing physical security. Some of those issues are the change of sites, traffic entering the site during working hours, and there are no clearly defined roles and duties for the security officer [7]. Proper structured site management can improve the quality of project performance [8].
Theft and vandalism are common actions occurred in a construction project. The loss due to the theft of materials, tools, and equipment at the project site in the United States (US) could be as high as four million dollars [9,10]. The number might be an underestimate due to the lack of theft is reported to the police and insurance companies [9]. The loss resulting from thefts can increase project cost up to $5 \%$ $10 \%$ of the total cost [9].

Construction site layout and security method and planning are essential to any construction project, and still widely unexplored [11]. Reference [10] suggest that region, project type, and project size are factors influencing a project's susceptibility to theft, extortion, and vandalism. It appears that there has been lacking research in Indonesia that examines the impact of security on project costs and schedule. Some studies have been done in other countries to identify the impact of thefts and vandalism on construction projects [12],[13],[14],[15],[16],[17],[18],[19]. This paper presents the analysis of the influence of project site security to the success of a construction project in Padang City. 


\section{MATERIAL AND METHOD}

A. The Review Theft, Extortion, And Vandalism In The Construction Industry Abroad

The definition of theft, according to the criminal law, is to steal other's property without permission of the owner. Extortion is a forcible takeover attempt of property rights or advantages. Vandalism is a violent action to break the property and or the project site and materials without removing material from the property [16].

Reference [15] surveyed 110 respondences and found that average loss due to vandalism in Florida was estimated at USD 3767 in three years. Among the various acts of vandalism, the breaking of glass, the destruction of material, and the graffiti are the most common. Nevertheless, the prevention of vandalism rarely becomes the concern of the contractor, as the cost of prevention is more expensive than the losses caused vandalism itself.

In his report, reference [17] explained that 39\% of residential projects in Australia experienced thefts and vandalism. The report states that the risks of theft and vandalism significantly increased when the project site was closer to the city center.

The average value of losses due to theft in housing projects is around AUD 2000 per project, while the value of losses due to vandalism reached 100 AUD. The types of material commonly stolen are building materials $(61 \%)$ and carpentry tools (46\%). More expensive materials for residential buildings such as the heating system are rarely to be stolen. Theft is prevalent in the final stage of the construction process in Australia.

A contractor company should consider its business history of recurring theft problems, e.g., how much the contractor typically has lost in past projects. The locality where the work is being done must also be taken into account when assessing the performance of a particular building site security plan. The role played by the location is evident and an important risk factor in recent research [15].

\section{B. The design of The Survey}

This study looked at two types of construction projects in Padang City. The first type is the general contract method that consists of a formally binding contract between contractor and owner, and the second type is a force account method. Note that, in the general contract method, the owner was responsible for drawing up the contract document, and the contractor would build the project. On the other hand, a force account method is a mechanism in which no contracts are written for a construction project. The owner must provide the materials, labor, equipment, and supervision [20]. The type of construction project would differ on the responsibility of the project's environmental security.

The projects were more than $75 \%$ complete at the time the survey was conducted to obtain the latest data. The number of samples was determined using a purposive sampling method. Five general contract projects and 34 force account projects in Padang City are used as a sample of this study.

Figure 1 and 2 depict the project cost for general contract method and the force account method, respectively.

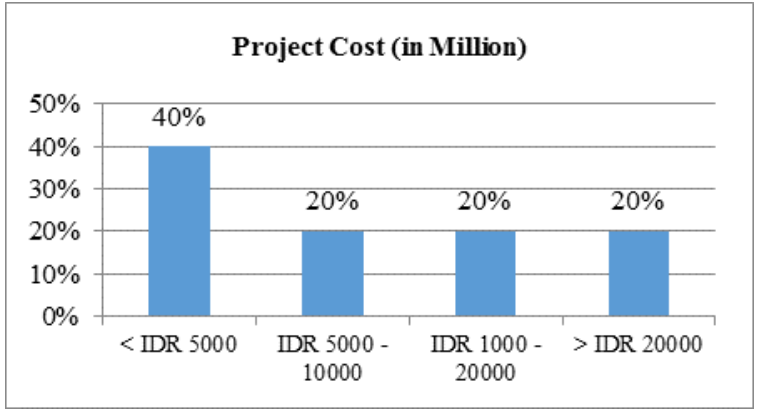

Fig.1. The project value for general contract method

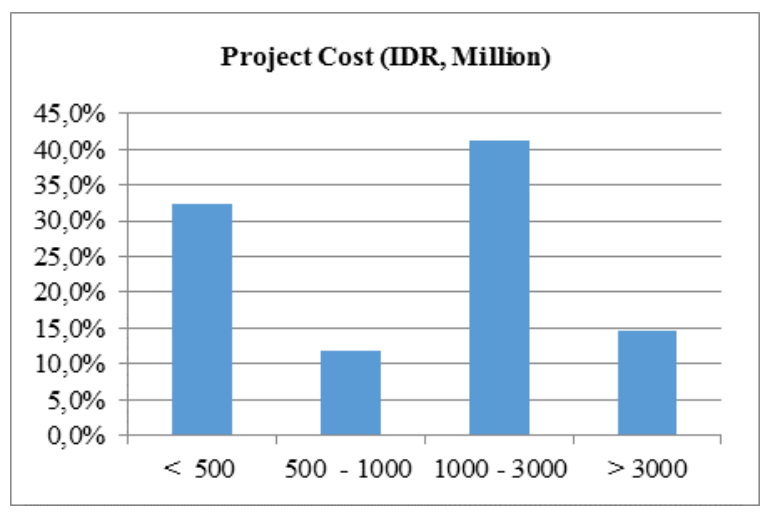

Fig.2 The project value for the force account method

Construction projects undertaken by the contractor are building projects, whereas the allotment of force account projects is shown in Figure 3:

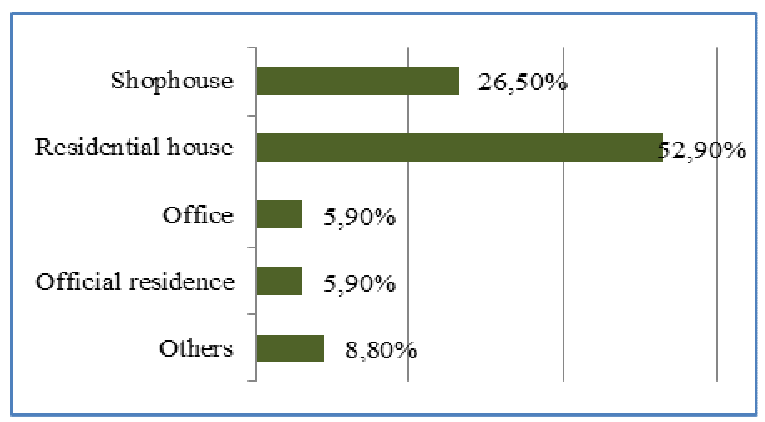

Fig.3 Allotment of Force Account Project

The matrix of variables needed in this study is shown in Table 1:

TABLE I

RESEARCH VARIABLES

\begin{tabular}{|l|l|l|}
\hline $\begin{array}{c}\text { Type of } \\
\text { Project }\end{array}$ & \multicolumn{2}{|c|}{ Research Variables } \\
\hline & Extortion & $\begin{array}{l}\text { The types of extortion, frequency } \\
\text { of occurrence, perpetrators, to } \\
\text { whom as victims }\end{array}$ \\
\cline { 2 - 3 } \begin{tabular}{l} 
1. General $\begin{array}{c}\text { Contract } \\
\text { 2. Force } \\
\text { Account }\end{array}$ \\
\cline { 2 - 3 }
\end{tabular} & Theft & $\begin{array}{l}\text { The frequency of occurrence, } \\
\text { value, and objects }\end{array}$ \\
\cline { 2 - 3 } & Vandalism & $\begin{array}{l}\text { The forms, the loss, the } \\
\text { perpetrators }\end{array}$ \\
\cline { 2 - 3 } & Protection \\
& Mechanism & The method, protection cost \\
\hline
\end{tabular}

Descriptive analysis is used in analyzing this research. The potential for theft, extortion, and vandalism are analyzed based on the objects of research and the 
recommendations. The stages of the construction project most vulnerable to theft, extortion, and vandalism are included.

\section{RESULT AND DISCUSSION}

A. The Effect of Theft, Extortion, And Vandalism on Construction Projects

The value of the loss resulting from theft, extortion, and vandalism on construction projects is obtained from the amount of loss that is incurred at the project site by comparison to project total costs. From Figure 4, 60\% of general contract projects and $41.2 \%$ of force account projects suffered theft during the construction process.

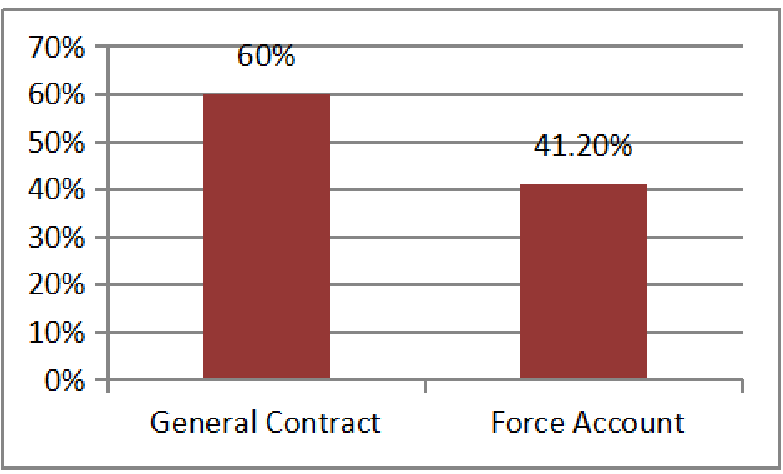

Fig. 5 The number of projects that experienced theft cases

The percentage of loss due to theft is calculated from the total value of theft losses to the total project cost, are shown in figure 6.

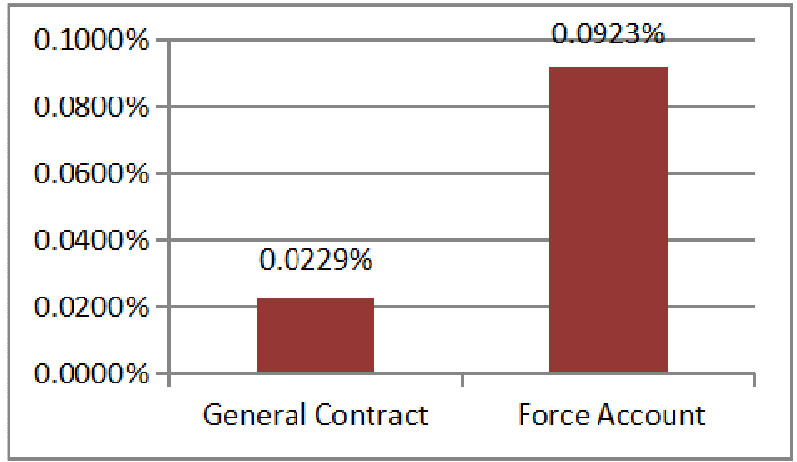

Fig. 6 The average percentage of theft losses to the total project cost

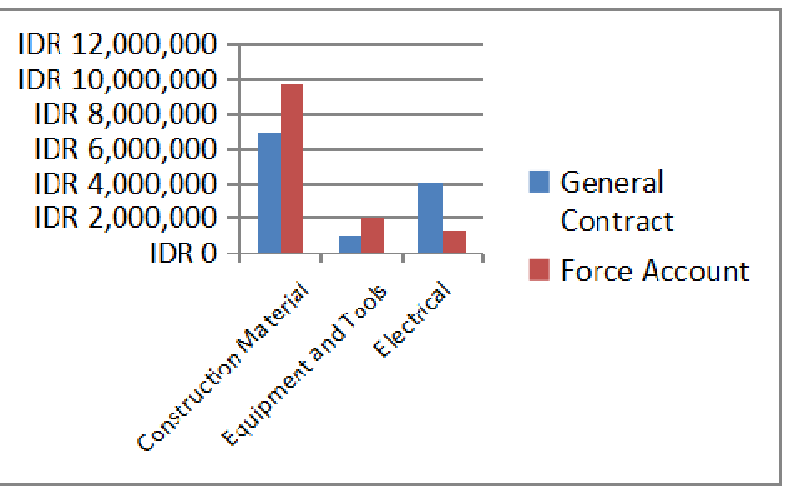

Fig. 7 The total value of theft losses for each type of material stolen
Figure 7 shows the total value of losses due to theft for each type of material stolen in these two type of projects. Construction materials are the most common stolen on the project sites. Figures 5, 6, and 7 indicated that theft occurred more frequently in general contract projects that are managed by the contractor. But the loss gained due to theft was bigger to the force account projects. The characteristics of extortion and vandalism are different from theft

The percentage of projects that experienced extortion throughout the construction process and the amount of loss due to extortion is as follows:

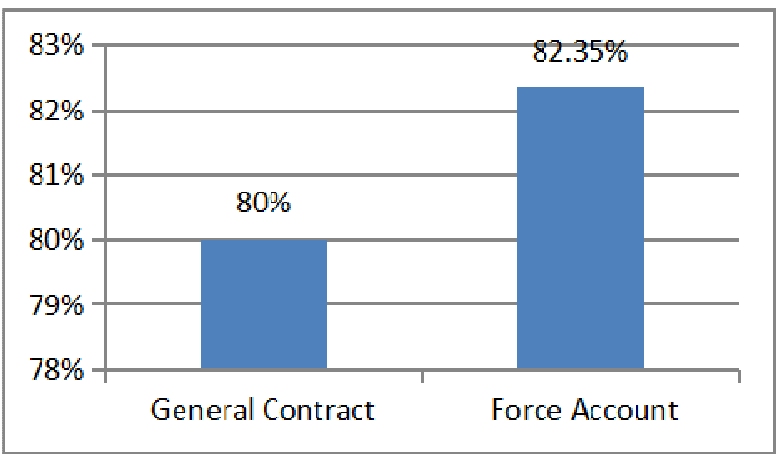

Fig. 8 The project that experienced extortion case

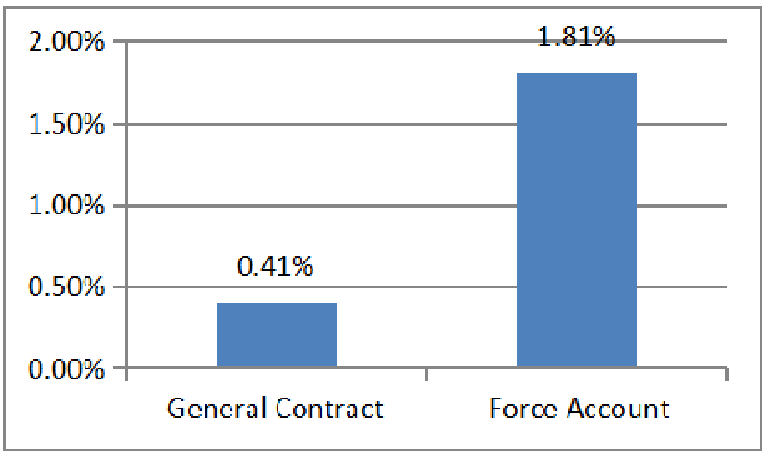

Fig. 9 The average percentage of extortion losses to the total project cost

Figures 8 and 9 indicated that extortion occurred slightly similar between general contract projects and force account projects. But the value of the loss of force account projects is four times higher than general contract projects. It is mean the force account projects are more risk to extortion case than general contract projects.

The percentage of construction project experiencing vandalism, and the amount of loss due to acts of vandalism are as follows:

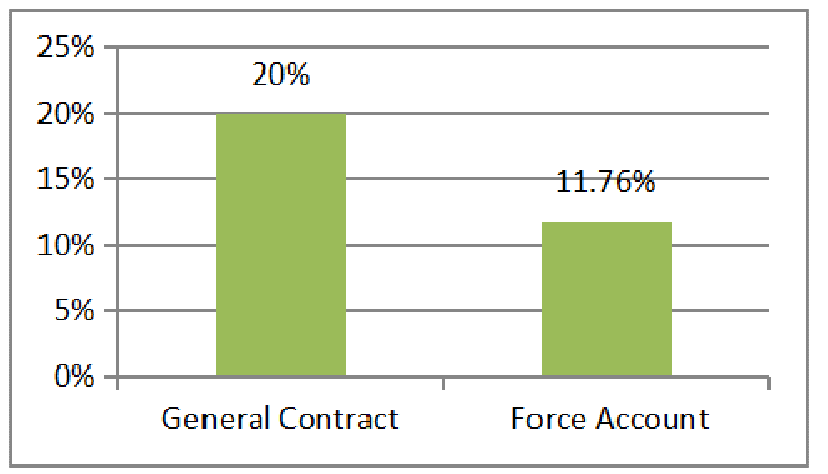

Fig. 10 The project that vandalism experienced 


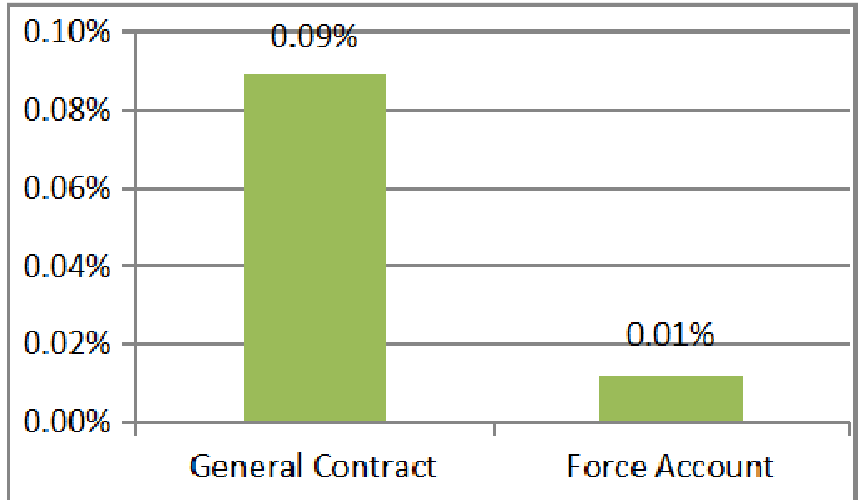

Fig. 11 The average percentage of vandalism losses to the total project cost

Figures 10 and 11 above indicated that vandalism occurred more frequently in the general contract project. Although the percentage of occurrence differs by $20 \%$ between the general contract projects and the force account projects, the value of the loss of general contract projects is nine times higher than force account projects.

The result of this research indicates that the force account projects are particularly vulnerable to extortion case, and the general contract projects are vulnerable to theft and vandalism cases. But the force account projects have a higher potential loss from security issues.

Theft, extortion, and vandalism that occurred did not influence the project implementation schedule. Because in general the material theft is limited to construction materials, work equipment, and electrical goods which are small in number and can be found easily on the market. Likewise, extortion only involved the owner of the project or the top level of the management, so that workers can work freely without disturbance.

Project security should be kept in mind as theft and extortion can also occur at the start of the project. Based on this research, the work of the substructure is the most vulnerable stage for the act of theft.

In general, it can be seen that security affects the project cost. The costs incurred to protect against theft, extortion, and vandalism of the project are higher than the cost of protection against these. Contractors rarely include the cost of security in the budget of their bid proposal.

Therefore, by lowering the percentage of security cost against the project overhead cost, the contractors will undoubtedly get a more significant profit. Maximizing the protection system is a critical element in ensuring the security of the project over the whole time of the project.

Similarly, force account projects must implement security management. A force account project is still vulnerable to theft and extortion because of the lack of safety fences and security personnel. The more frequent theft and extortion that occur on force account projects will increase the project cost.

\section{B. Mechanism of protection}

Vulnerability to these three security issues is related to the protection employed by the projects. Most of the suspected perpetrators in force account projects are people who work in the project, including the builders. In contrast, perpetrators of theft in contractor controlled projects are less likely to be workers on the project but from outside.

In the case of theft, the most frequently stolen items are construction materials and tools that are easy to carry. Figure 12 shows the types of materials and construction equipment that are the most frequently stolen in force account projects.

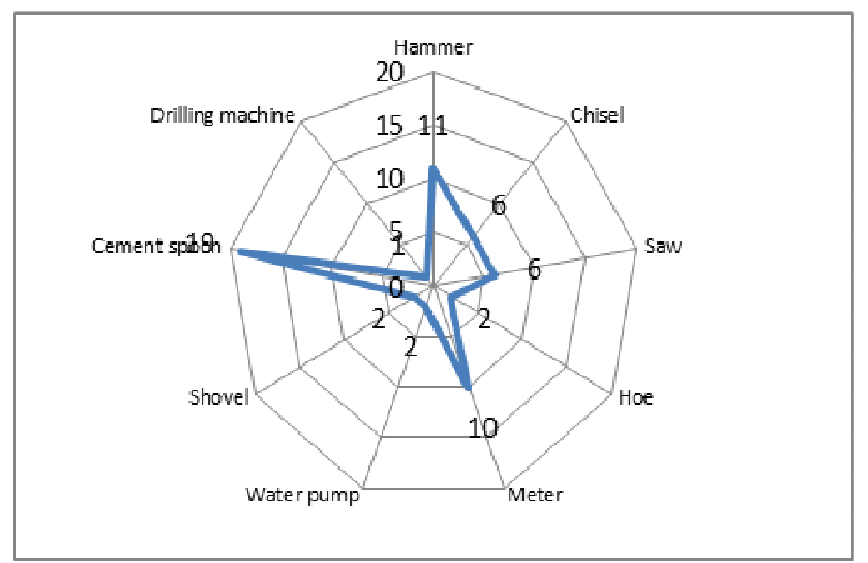

Fig. 12 The construction tools that are frequently stolen in force account project

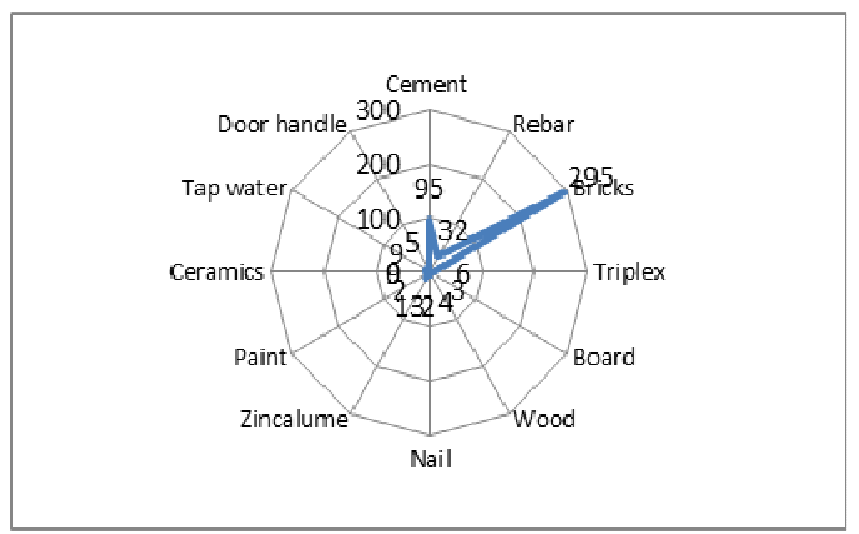

Fig. 13 The construction materials that are frequently stolen in force account project

The type of construction materials stolen on general contract projects is quite similar to the force account project. But the types of construction tools and the number of stolen items are much reduced on the general contract projects. It is noted that contractors only experienced theft on tools such as cement spoon, hammer, and measuring tape.

The reason for the minimum occurrence of theft in contractor managed is that the contractors have better security measures. The contractors have site office and warehouse in the area that minimizes access for the opportunist theft. The contractors also have better logistics management. The amount of stock left on sites should be kept to an absolute minimum. Unattended materials present an opportunity for thieves and vandals.

A countermeasure is developed to mitigate the threat and the resulting vulnerability that was discovered in the assessment. A countermeasure can be one or a combination of the following: intrusion detection systems, security officers, access control, perimeter controls, CCTV, and security lighting [7]. 
The protection against theft, which is carried out by the contractors, is depicted in Figure 14.

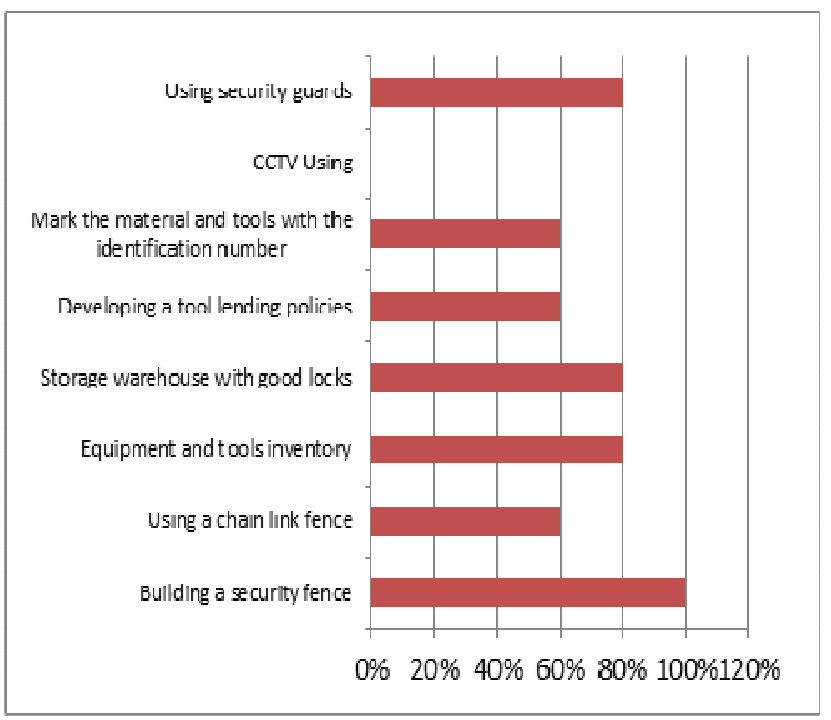

Fig.14 The percentage of a protection mechanism for the theft case

General Contractors used many methods of protection mechanism to maintain security. All of the general contract projects use security fence. To improve security at project sites, general contractors need to use CCTV and security lighting at night. The contractor on the project site does not use these two methods.

Not all of these methods of protection can be applied for the force account projects. Most force account projects are for residential buildings. They do not build security fences around the project sites and do not use the services of security personnel. However, other methods are minimally applied to force account projects in overcoming the act of theft, including off-site.

Assembling of construction materials, for instance, steel reinforcement, also may be used to the construction site, which is not too far from the location of depository [21]. Besides to reduce the cost of transport, using material assembly can increase the safety of the construction site.

Best-practice stock logistics from general contract projects can help force account projects. Just-in-time delivery scheduling could be employed, delivery times could alternate, and there should always be someone trustworthy to accept the delivery. If materials have to be ordered in bulk, these should be stored in a security compound or an area where theft will be noticed quickly.

The frequent occurrence of extortion and the extent of losses incurred on force account projects in Padang City need to be noted. The majority of losses comes from the retribution that is demanded by local youth (gangs) to the project owner. The requirement of employing people from the surrounding communities also happens to the project undertaken by contractors. Also, there are still unreasonable charges for unloading material and bringing heavy equipment out.

Therefore, by strengthening the project site security personnel and improving the relationship with the community and local youth leaders, it is expected that extortion can be minimized. Strengthening and implementing the protection system, as shown in Figure 14 above, will also help avoid vandalism against the project site. Moreover, as incidences of theft, vandalism, and extortion are rarely reported to the police officer, contractors and owners should consider informing police when such events occur.

Automatic identification of construction safety issues using Building Information Models can be used as a proactive method to secure the construction site [22]. The contractors can estimate the cost of project security equipment at the beginning of the project. Although the initial data is not fully available, the contractor can use the Neural method to estimate the security costs of the project [23]. In the future, the contractor can select the most effective security measures within budget constraints and the use of economic indicators as a tool in decision analysis [24, 25].

\section{CONCLUSION}

Problems of theft and vandalism are paramount issues related to building sites. In Padang city, extortion also commonly occurs and is a known problem. The literature review revealed that these losses had been identified in previous studies n United State of America and Australia. There has been little research in Indonesia that examines the impact of project costs due to criminal activity at a construction site.

Based on five general contract projects and 34 force account projects, it can be shown that construction projects in Padang city are subject to theft, extortion, and vandalism during their construction process. A good project management form is required so that extortion, which is the most common security problem, does not have a significant impact on the cost and schedule of the project.

If both contractor and force account project owners can prioritize effective communication with stakeholders who are either directly or indirectly involved, then this should lead to fewer instances of theft, extortion, and vandalism. This will include giving information about the project to the community leaders, the local youth leaders, and the residents around the project (neighborhood watch).

Theft, extortion, and vandalism are the risk that should be identified at the beginning of the project. Maximizing the protection system is the key to ensuring the security of the project by running it from the beginning of the project, and continued up to the lower and upper structure.

The lack of initiating to identify the risk of the project will affect to project itself. Some barrier and project constraint is becoming a risk at this point that does not recognize at risk for the entire project without a systematical method [26].

\section{ACKNOWLEDGMENT}

Publication of this article is supported by the Head of Civil Engineering Department, Faculty of Engineering Andalas University 


\section{REFERENCES}

1. R. Vidhyasri, R.S., A Review on Factors Influencing Construction Project Scheduling. International Journal of Civil Engineering and Technology (IJCIET), March 2017. Volume 8(Issue 3).

2. Sinesilassie, E.G., Critical factors affecting schedule performance: A case of Ethiopian public construction projects - engineers' perspective. Indian Institute of Technology Delhi, New Delhi, June 2016.

3. Z. Linlin, J.M.a.N.D., Exploratory Factors Influencing Building Development Costs in New Zealand. School of Engineering and Advanced Technology, Massey University, 0632 Auckland, New Zealand, MDPI, 29 June 2017.

4. R Rajaprabha, V.P., Jayanthi B, Factors Affecting The Cost Of Building Material In Construction Projects. International Journal of Science and Engineering Research (IJOSER), April 2016. Vol 4 (Issue 4).

5. R.Vidhyasri, R.S., Assessment of Influencing Factors in Construction Project Scheduling. International Journal of Applied Engineering Research, 2018. Volume 13, Number 8.

6. Oyedele, O.A., Evaluation of Factors Affecting Construction Cost Estimation Methods in Nigeria. Research Gate, May 2015.

7. Arata, M.J., Construction Site Security. McGraw-Hill, 2006.

8. O. Ayodeji, C.A., Ernest Dlamini, Factors Affecting Quality of Construction Projects in Swazilland. The Ninth International Conference on Construction in the 21st Century (CITC-9). Dubai, United Arab Emirates, March 2017.

9. R. Boba, R.S., Review of the Research, Practice, and Evaluation of Construction Site Theft Occurrence and Prevention: Directions for Future Research. Security Journal, Palgrave Macmillan, 2008.

10. R. Berg, J.H., Theft and Vandalism on Construction Sites. Journal of Construction Engineering and Management, ASCE, 2005. Volume 131 Number 7.

11. Z. Li, W.S., J Xu, B. Lev, Bilevel and Multi-objective Dynamic Construction Site Layout and Security Planning. Automation in Construction, Elsevier, 2015.

12. Police Department, K. Controlling Theft and Vandalism at Construction Sites. Available from: https://rccustomers.travelers.com/riskcontrol/rcpublicdocs.nsf/0/2E24 E1FACFBFD35D8525751500767727/\$FILE/090205\%20control\%20 theft $\% 20$ vandalism\%20const $\% 20$ sites.pdf.
13. Crime Alert. Preventing building site theft and vandalism. 2006 Available from: http://www.neighbourhoodwatch.com.au/building/publicationsmain.h $\underline{\mathrm{tml}}$

14. Lang, R., Health and safety on construction site-construction international. 2008.

15. O. Farinloye, K.O., Y. Adewunmi, Theft and Vandalism Control Measures on Building Sites in Lagos, Nigeria. Journal of Engineering, Project, and Production Management, 2013. Volume 3 No 1.

16. Berg, R., Jobsite Security On Commercial Construction Projects. Thesis, Florida University, 2003.

17. Y. Sakurai, P.M., M. White, Theft and vandalism at residential building sites in Australi. Australian Institute of Criminology, 2008.

18. Setiani, Y., Construction Site Security Management and Control. Master Tesis, University Teknologi Malaysia, 2008.

19. Carney, K.W., The Impact of Construction Site Theft - Securing The Outdoor Construction Site Strategy, Prevention and Mitigation. Butterworth Heinemann, 2016.

20. Hinze, J., Construction Contract. McGraw-Hill, 1993.

21. Gardner, T. Security in Construction and Beyond, Protecting your site, even during build-up. 2002; Available from: http://old.insideselfstorage.com/articles/291feat4.html.

22. H. Malekitabar, A.A., M. Hassan Sebt, R. Stouffs, Construction Safety Risk Drivers : A BIM Approach. Safety Science,, February 2016. Volume 28.

23. Khalel, T.A.M., Development of The Artificial Neural Network Model for Prediction of Iraqi express Way Construction Cost. International Journal of Civil Engineering and Technology, October 2015. Volume 6(Issue 10)

24. V. Villa, G.L.L.R., N. Patrinieri, V. Cozzani, Development of an Economic Model For The Allocation of Preventive Security Measures Against Environmental and Ecological Terrorism in Chemical Facilities. Process Safety and Environmental Protection, July 2017. Volume 109.

25. V. Kankhva, D.S., Formation of Mechanism of Facilitating and Enhacing of Economic Security of Investment Project in Construction of Underground Facilities. Procedia Engineering, 2016. Volume 165.

26. A. Hamid, I.B., W. Sani, Risk Management Framework in Oil Field Development Project by Enclosing Fishbone Analysis. International Journal On Advance Science, Engineering and Information Technologies, 2017. Vol 7 Number 2. 